К. Г. Ковцур, Н. В. Птиця, В. Ю. Федоров

Харківський національний автомобільно-дорожній університет, Харків, Україна

\title{
ДО ПИТАННЯ ВИЗНАЧЕННЯ ЧАСУ ЗНАХОДЖЕННЯ АВТОМОБІЛІВ У ПУНКТАХ НАВАНТАЖЕННЯ ТА РОЗВАНТАЖЕННЯ
}

\begin{abstract}
Анотація. Розглядаються особливості роботи транспорту у ланцюзі постачань. В роботі наведене обгрунтування причин виникнення непродуктивних простоїв транспорту у пунктах навантаження та розвантаження. Визначені складові витрат часу автомобіля та фактори зовнішнього середовища впливу на них. В роботі запропонований підхід до визначення часу знаходження автомобілів у пунктах навантаження та розвантаження, який дозволить оцінити ефективність роботи транспорту.
\end{abstract}

Ключов і слов а : перевізник, час простою, навантаження, розвантаження, продуктивність автомобіля, транспортний засіб.

\section{Вступ}

На сьогодні транспорт є запорукою існування економіки країни та держави в цілому. Більша частина перевезень припадає саме на автомобільний вид транспорту. Складовою частиною, від якої залежить значення продуктивності та загальних витрат на виконання процесу перевезення вантажів, $є$ непродуктивні простої транспортних засобів, що виникають, переважно, у пунктах навантаження та розвантаження.

Сьогодні ринок диктує такі умови, в яких автотранспортні перевізники знаходяться у положенні «заручника» ситуації. Виконуючи замовлення перевізники не мають ніякої впевненості, що транспортний засіб буде обслуговано в пунктах навантаження та розвантаження в зазначений в замовленні термін, що місце призначення не зміниться після укладення договору та заявки на транспортування та, врештірешт, замовлення не буде скасовано взагалі. У даних умовах перевізникам майже не можливо спланувати роботу транспортних засобів. Для якісної роботи автотранспортного підприємства, логіст до підписання заявки на перевезення має знайти зворотне завантаження для уникнення витрат часу, пов'язаних з простоєм транспорту через пошук замовлення на перевезення. При цьому при виконанні замовлення 3 великою вірогідністю на них чекають непродуктивні простої у пунктах навантаження та розвантаження, переадресації та повернення товару, через які, не маючи інших рішень, перевізники змушені відмовлятися від зворотного завантаження, а іноді навіть і сплачувати штрафи за ненадання транспорту під навантаження в зазначений термін.

Через неякісну організацію процесу навантаження та розвантаження транспортні засоби можуть мати простої до декількох діб через відсутність вантажу або вантажників, неякісний вантаж, велику чергу тощо. Середня вартість простою автомобіля по Україні складає 500 грн за добу, при тому що перевізнику потрібно платити добову заробітну плату водію, яка може складати більшу частину цієї суми.

Ситуація на ринку транспортних послуг носить стохастичний характер, що ускладнює роботу автотранспортних підприємств. Розробка моделі часу навантаження та розвантаження дозволить зменши- ти загальні витрати всіх учасників транспортного процесу та якісно спланувати роботу перевізникам. Виходячи з мети роботи треба визначити групу параметрів, що характеризують умови перевезень i впливають на показники роботи транспорту у пунктах навантаження та розвантаження при доставці товарів на склад.

Аналіз публікацій. Визначення часу навантаження або розвантаження в системі доставки вантажів представлене в роботах вчених, таких як Курейчик В.М., Рокотянський А.А., Мочалін С.М., Володіна А.М., Тарасюк Ю.В. та ін.

Норми часу, які витрачаються транспортними засобами під навантаженням або розвантаженням, для визначення економічних показників роботи та для визначення продуктивності роботи транспорту часто приймаються з Прейскуранта 13-01-02 [1], але вони мають тільки рекомендаційний характер, та на сьогодні є застарілими, майже не використовуються логістами через похибку фактичних значень від нормативних. Ці норми часу визначались емпіричним шляхом в 90-х роках, тому через великий проміжок часу мають уточнюватись та корегуватись. Також невідомо, яким чином формувалися ці нормативи, невідома кількість спостережень та їх тривалість.

Автор у роботі [2] припускає, що скорочення тривалості простою автомобіля в пунктах навантаження та розвантаження вантажу може бути досягнуто за умови:

- раціональної організації та технології навантажувально-розвантажувальних робіт в пунктах відправлення і прибуття вантажу;

- підвищення рівня механізації НРР шляхом заміни ручної праці на механізовану та впровадження більш продуктивної конструкції засобів механізації.

Проведені дослідження залежності продуктивності автомобіля від часу його перебування в пунктах навантаження й розвантаження показують, що добова продуктивність автомобіля при незмінних часу на маршруті, номінальної вантажності та статичного коефіцієнту використання вантажопідйомності виявляється у зворотній пропорційній залежності від тривалості їздки автомобіля $t_{\mathrm{i}}$. Звідси виходить, що за рахунок скорочення часу на поїздку автомобіля можна збільшити його продуктивність. 
В.М. Курейчик та А.А. Рокотянский [3] пропонують методику визначення часу навантаження/розвантаження, яка враховує наступні фактори: тип товару, число одиниць товару та число вантажівок. Змінними у даному випадку є порядки під'їзду і від'їзду автомобілів. Отже, за думкою авторів, час роботи буде напряму залежати від цих двох перестановок.

В роботах багатьох вчених методика визначення часу навантаження/розвантаження в явному вигляді не представлена $[4,5]$. Часто в роботах вчених задається час на одну тону певного вантажу, які не обгрунтовуються, або ж використовується середне значення $[7,8]$. Найчастіше дослідники роблять посилання на [9]. Цей документ складався у 1987 році, що за фактором часу також має бути уточненим та переглянутим згідно сучасних умов, що впливають на транспортний процес. Автор [10] пропонує визначення часу обслуговування виходячи зі способу й організації навантажувально-розвантажувальних робіт, кількості вантажу, що підлягає навантаженню, обсягу попутного збору та витрати часу на навантажування та розвантажування однієї тони вантажу. Фактичний час обслуговування має непостійний характер, що свідчить про його коливання, тим самим цей спосіб визначення даного показника недоцільний, тому що похибка $є$ досить значною. У [11] час простою автомобіля під час виконання вантажно-розвантажувальних операцій визначається, перш за все, продуктивністю механізмів, що обслуговуються. Кожен вантажний пункт являє собою окремо функціонуючу систему зі своїми витратами часу на обслуговування, які залежать від ряду факторів: оснащення механізмами різної продуктивності; вантажі, запропоновані до перевезення, можуть ставитися до різних класів, і відповідно до цього буде різна ступінь використання номінальної вантажопідйомності автомобілів; витратами часу на виконання супутніх операцій (маневрування, зважування, заповнення необхідних документів.

У роботі Мочаліна С.М. [12] проведені натурні спостереження (пасивний експеримент) за зміною часу простою стосовно одного автомобіля за кілька днів місяців. Автор описує перманентні коливання часу навантаження, в результаті чого час простою під навантаження/розвантаження по днях. Автор зазначає, що якщо планувати роботу по середньому часу простою, то це щодня буде приводити до помилок. Встановити закономірність коливань часу простою автомобіля за допомогою відомих законів розподілу не виявилося можливим, значення величини часу простою $є$ випадковим імовірнісним, а математичний опис вимагає уточнення. Величину помилки при плануванні можна зменшити, якщо щодня (щозміни) при визначенні можливого числа їздок (обертів) використовувати середнє значення часу простою автомобіля під навантаженням та розвантаженням, розрахованого, виходячи 3 реальних витрат часу на виконання вантажних операцій, тому що час простою залежить від технічних можливостей вантажних механізмів, а також від кількості вантажу, що підлягає навантаженню та розвантаженню.
Усі вищезгадані автори відзначають суттєвий вплив часу знаходження транспортного засобу в пункті навантаження / розвантаження на ефективність роботи транспорту, але в наведених роботах не приводиться чітких методик визначення впливу факторів на час знаходження транспортного засобу у пункті.

Мета і постановка задачі. Сучасний стан ринку не дає можливості перевізникам планувати роботу транспортних засобів з метою збільшення їх продуктивності. Не можливо спрогнозувати, коли автомобіль буде навантажено або розвантажено: одразу після прибуття до місця призначення або через декілька годин чи діб. Врахування можливих коливань часу перебування у пунктах навантаження / розвантаження дозволило б підвищити ефективність перевізного процесу. Тому метою роботи є: знаходження параметрів, які, повною мірою, характеризують умови перевезень і впливають на показники роботи транспорту у пунктах навантаження та розвантаження при доставці товарів на склад, що дозволить підвищити продуктивність транспорту в ланцюзі постачань.

\section{Суть пропозиції}

Час знаходження автомобіля у пункті навантаження чи розвантаження можна представити як суму певних відрізків часу. Час знаходження автомобіля у пункті навантаження (розвантаження) визначається цільовою функцією, яку можна представити як

$$
t_{H(p)}=t_{M}+t_{o}+t_{\text {обсл }}+t_{n}+t_{\partial} \rightarrow \min ,
$$

де $t_{\mathrm{M}}$ - час маневрування, год.; $t_{\mathrm{o}}$ - час очікування обслуговування, год.; $t_{\text {обсл }}$ - час обслуговування, год.; $t_{\text {п }}$ - час, який потребується на прийом вантажу (при навантаженні $t_{\mathrm{n}}=0$ ), год.; $t_{\text {д }}$ - час оформлення документів, год.

Час простою автомобіля у пункті навантаження (розвантаження) має у своєму складі багато показників, що мають вплив на кінцеве його значення (рис. 1). Вагомими факторами, що мають вплив на час знаходження автомобіля під навантаженням/розвантаженням є ритм складу $(R)$, вантажність автомобіля $(q)$, ціна вантажу (Ц), час очікування навантаження або розвантаження $\left(t_{0}\right)$, час оформлення документів $\left(t_{\text {д }}\right)$.

Однісю $з$ основних причин виникнення простоїв рухомого складу в очікуванні навантаження і розвантаження $\epsilon$ невідповідність ритму роботи навантажувального пункту і інтервалу руху автомобілів. Якщо інтервал руху автомобілів менше ритму роботи пункту навантаження (розвантаження), виникають простої рухомого складу в очікуванні навантаження (розвантаження), при зворотному співвідношенні виникають простої вантажних механізмів. Ритм складу є невід'ємною частиною якісної організації транспортного процесу. Цей фактор вказує на ефективність організації роботи складу та має обернено пропорційний вплив на продуктивність автомобіля, тобто чим менше значення ритму, тим продуктивність більша. Наприклад, в умовах безперебійної роботи значення цього показника визначає кількість транспортних засобів, що мають бути задіяні у виконанні переміщення вантажу. 


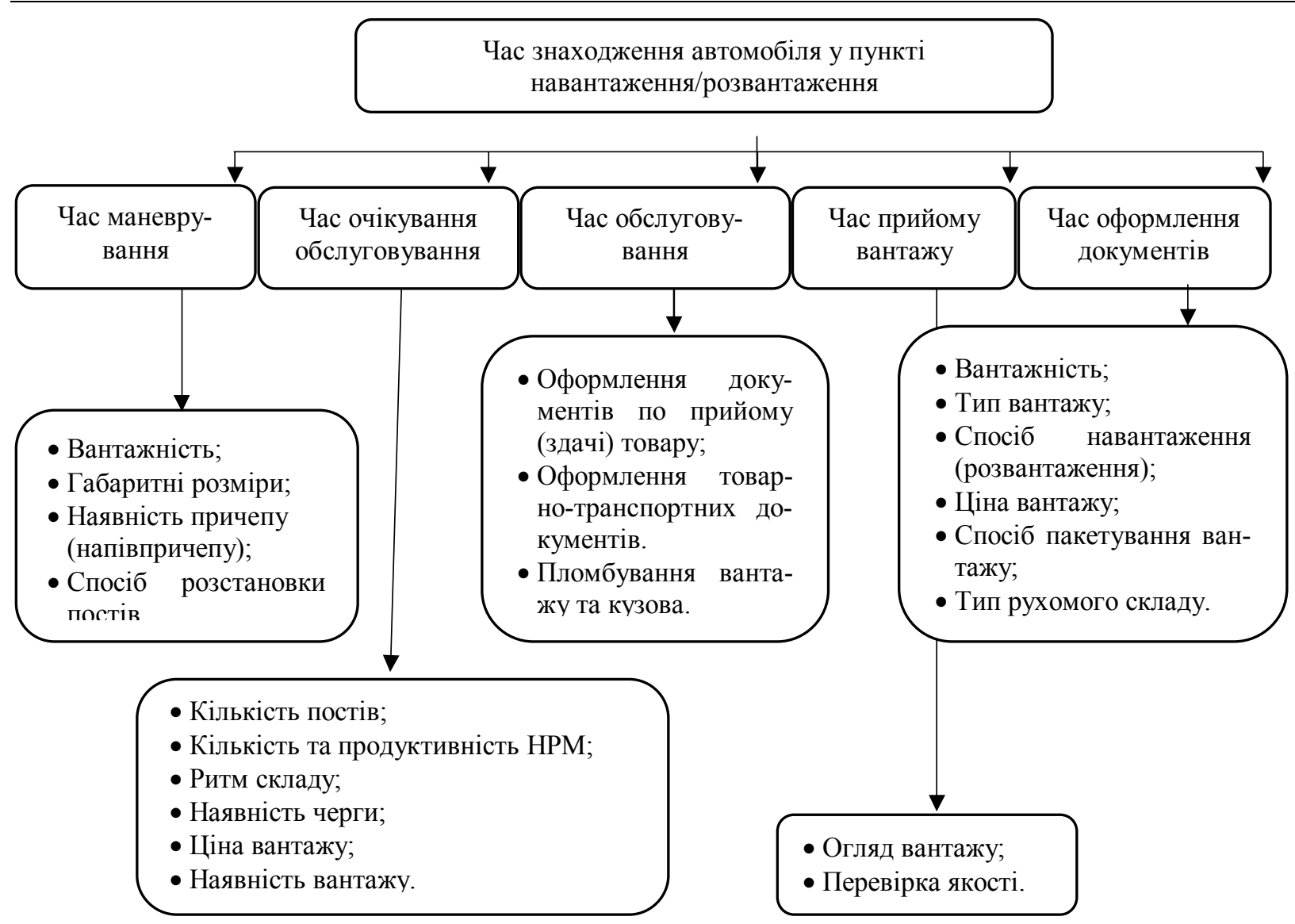

Рис. 1. Структура часу знаходження автомобіля у пунктах навантаження та розвантаження

Ритм роботи пунктів навантаження / розвантаження визначається

$$
R=\frac{t_{\text {обсл } \cdot \eta}}{X_{n}}
$$

де $X_{n}$ - кількість навантажувально-розвантажувальних механізмів, од.; $\eta$ - нерівномірність прибуття автомобілів.

Від вантажності транспортного засобу залежить величина часу маневрування автомобіля у пункті навантаження (розвантаження). Також вантажність автомобіля впливає на першочерговість обслуговування.

Так, наприклад, маловантажні автомобілі обслуговуватимуться першими, так як трудомісткість та час цього обслуговування буде меншим, хоч це і не завжди є ефективним. Час очікування обслуговування у сучасних умовах може складати більшу частину всього часу перебування у пункті навантаження або розвантаження, в виробництві його спрогнозувати дуже важко

$$
t_{o}=t_{\text {обсл }}^{1}+t_{\text {обсл }}^{2}+t_{\text {обсл }}^{n}
$$

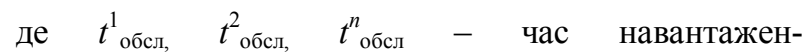
ня/розвантаження автомобілів, що обслуговуються та тих, що обслуговуватимуться наступними, год.

Цей непродуктивний простій призводить до великих збитків та втрат транспортного підприємства, компенсування яких неврегульовано, сума цієї компенсації зазвичай $є$ незначною та не покриває пов- ною мірою витрати перевізника як в явному виді, так i опосередковано. Тому перевізники наперед страхують свій прибуток підвищенням фрахту на виконання замовлення, що насамперед позначається на вартості товару на полках роздрібного торговця. Тобто за погану організованість роботи перевізного процесу «платить» кінцевий споживач.

У залежності від ціни вантажу, прийнятого до перевезення, залежить спосіб розвантаження (навантаження), черга обслуговування, збереження вантажу, а також час обслуговування. У ціну включено пакетування вантажу, наприклад, картопля у сітках значно дешевша за ту ж саму картоплю на піддонах, а отже картопля у сітках завантажена навалом не матиме пріоритет у черговості, трудомісткість та час обслуговування буде більшим, а також кузов транспортного засобу після розвантаження потребуватиме подальшого очищення. Ціна вантажу включає такі складові:

- собівартість одиниці продукції;

- обсяг вантажу;

- прибуток.

Також один 3 невиправданих простоїв у пункті навантаження та розвантаження $\epsilon$ очікування оформлення документів. Цей час $є$ меншим за час очікування обслуговування, але його вплив на збитки та втрати автотранспортних підприємств є значними. За нормативами цей час становить 15-20 хвилин, що має принципову відмінність від того ж самого часу у фактичному представленні. Перевізники змушені відмовлятися від нового замовлення, так як клієнти 
потребують негайного навантаження, а транспортний засіб знаходиться у стані очікування документів i проміжок часу до моменту отримання транспортних документів про прийняття товару є стохастичною величиною. Цей час як детерміновану модель можна представити таким чином:

$$
t_{\partial}=t_{m m}+t_{n m}+t_{n л},
$$

де $t_{m m}$ - час оформлення товарно-транспортних накладних, год.; $t_{n m}$ - час оформлення документів прийому (здачі товару), год.; $t_{n л}-$ час пломбування вантажу та кузова, год.

\section{Висновки}

В результаті проведеного дослідження сформульовані складові часу перебування транспортного засобу у пунктах навантаження та розвантаження 3 урахуванням можливих простоїв. За допомогою отриманої математичної моделі обрані фактори, які впливають на тривалість знаходження автомобіля у пунктах, що дозволить підвищити ефективність усього перевізного процесу. У подальшому доцільним є розробка регресійної моделі, до складових якої входять обрані фактори, що дозволить визначити ступінь впливу їх на залежну змінну.

\title{
СПИСОК ЛІТЕРАТУРИ
}

1. Прейскурант N13-01-02. Тарифы на перевозку грузов и другие услуги, выполняемые авто-мобильным транспортом. - Киев: Госкомцен УССР. - 1989. - 56с.

2. Северин, О. О. Оптимізація критерію оцінки ефективності технології доставки тарно-штучних вантажів/ О. О. Северин, О. О. Шуліка // Автомобильный транспорт : сб. науч. тр. / М-во образования и науки Украины, ХНАДУ - Харьков, 2017. - Вып. 40. - С. 20-23.

3. Курейчик В.М. Генетический алгоритм решения логистической задачи / В.М. Курейчик, А.А. Рокотянский // Известия ЮФУ. Технические науки. - Таганрог: ТРТУ, 2012. - №136 -c. 245-251.

4. Куш Е. И. Планирование транспортного процесса перевозки грузов в условиях города (на примере города Харькова) / Е. И. Куш, А. С. Галкин, Н. А. Фиялко // Комунальне господарство міст. Серія: Технічні науки та архітектури. 2016. - Вип. 132. - С. $98-103$.

5. Уланкова Н.А. Формирование объемов деятельности предприятий автомобильного транспорта, НОУ СПО «ГорноАлтайский экономический техникум Респотребсоюза РА». -230 с.

6. Скрипін В.С. Визначення оптимальної вантажопідйомності транспортних засобів залежно від схем розвезення вантажів в логістичній системі / В.С. Скрипін, С.І. Куш // , ХНУГХ, 2016.- С. 70-75.

7. Рыжиков Ю.И., Теория очередей и управление запасами / Учебное пособие, для вузов. — СПб.: Питер, 2001. - 384 c.

8. Chung-Lun Li Loading and unloading operations in container terminals / Chung-lun Li, George L. Vairaktarakis // Volume 36, 2004 - Issue 4 - P. 287-297.

9. Единые нормы времени на перевозку грузов автомобильным транспортом и сдельные расценки для оплаты труда водителей. Госкомтруда СССР, 1987. - Режим доступу: https://zakon.rada.gov.ua/laws/show/v0142400-87 .

10. Воркут А. И. Грузовые автомобильные перевозки. - Киев: Высш. шк. Головное изд-во, 1986. - 140c.

11. Мочалин С.М. Анализ влияния времени погрузки и разгрузки подвижного состава на эффективность функционирования автотранспортной системы доставки грузов / С.М. Мочалин, А.М. Володина// Транспортное дело России, 2011. - Вып. 5. - С. 132-135.

12. Мочалин С.М. Математическая модель описания транспортного процесса в средних системах доставки грузов // Вестник ОГУ. - 2004. - № 2. - С. 185-189.

Надійшла (received) 18.12.2019

Прийнята до друку (accepted for publication) 22.01.2020

\author{
About determining the time of vehicles \\ in the loading and unloading points \\ K. Kovtsur, N. Ptitsa, V. Fedorov
}

\begin{abstract}
The study in the article is the parameters of unproductive transport downtime at loading and unloading points. The aim of the study is to identify the parameters that fully characterize the operating transport conditions at the loading and unloading points during the delivery of goods between warehouses, the optimization of which will improve the productivity of transport in the supply chain. Research problems: to identify the causes of unproductive transport downtime at loading and unloading points; to determine the components of the time of stay the vehicle at the loading / unloading points and the factors of the external environment impact on them, developing an approach to determine the time of stay the vehicle at the loading and unloading points, which will allow to evaluate the efficiency of transport. The following results are received: a critical analysis of existing approaches to determining the time of loading / unloading of a vehicle at the loading / unloading points made it possible to identify the absence of specific recommendations for the determination of the studied parameter of the transportation process; the use of the proposed approach to determining the time of stay the vehicle at loading and unloading points is substantiated; factors affecting the loading / unloading time were identified. Conclusions. As a result of the study, the components of the vehicle's residence time at loading and unloading points were formulated taking into account possible downtime. With the mathematical model obtained, the factors influencing the duration of the vehicle stay in the items were selected, namely the rhythm of the warehouse, the vehicles load capacity, the cost of cargo, the waiting time for loading or unloading, and the processing of documents. In the future, it is advisable to develop a regression model, the components of which are the selected factors, which will determine the degree of their influence on the dependent variable.
\end{abstract}

Keywords : carrier, idle time, loading, unloading, vehicle performance, vehicle. 